\title{
Wybrane aspekty duchowości biblijnej w pismach św. Urszuli Ledóchowskiej
}

Święci, założyciele zakonów, zgromadzeń czy stowarzyszeń życia apostolskiego byli ożywiani przede wszystkim przez dążenie do wypełniania Ewangelii, najczęściej jakiegoś określonego jej aspektu. Słowo Boże i natchnienie Ducha Świętego sprawiały i nadal sprawiają, że powstają nowe charyzmaty w Kościele. Jan Paweł II zauważa, że „nie można myśleć o dziele założycieli, nie widząc w nich wcielenia Ewangelii, obejmującego geografię i historię Kościoła"². Żywotność charyzmatu jest oparta na wierności Ewangelii oraz wskazaniach założycieli inspirowanych słowem Bożym. Założyciele, wychodząc z jednoznacznej perspektywy słowa Bożego, dawali przykład kształtowania życia według ducha Ewangelii. Właśnie dzięki mocy słowa Bożego byli zdolni skutecznie i ofiarnie wcielać miłość Chrystusa nie tylko mową, lecz także przez czyny, przez swoje zaangażowanie. Pozostawione przez nich rodziny zakonne kontynuują misję głoszenia królestwa Bożego, pod warunkiem że u podstaw myśli, słów i działań zakonników i zakonnic pozostaje Ewangelia ${ }^{3}$.

Święta Urszula Ledóchowska (1865-1939), założycielka Zgromadzenia Sióstr Urszulanek Serca Jezusa Konającego, kierowała się w życiu pragnieniem wypełnienia słów Chrystusa zawartych w Ewangelii. Pismo Święte stanowiło dla niej podstawowe odniesienie. Niniejszy artykuł ma na celu przedstawienie wy-

\footnotetext{
${ }^{1}$ Siostra dr Małgorzata Pagacz USJK należy do Zgromadzenia Sióstr Urszulanek Serca Jezusa Konającego, ul. Wiślana 2, 00-317 Warszawa; e-mail: mmpagacz@gmail.com. ORCID: 00000003-4504-9142.

2 Jan Paweł II, Przemówienie do zakonników w sanktuarium Serca Jezusowego w mieście Guatemala: Żywy depozyt charyzmatu założycieli [w:] tegoż, O życiu zakonnym. Przemówienia Listy Apostolskie — Instrukcje, red. E. Weron, A. Jaroch, Poznań-Warszawa 1984, s. 245.

${ }^{3}$ Zob. tamże.
} 
branych aspektów duchowości biblijnej w pismach Matki Ledóchowskiej. Ukazuje wartość i znaczenie Biblii na podstawie Rozmyślań św. Urszuli, analizuje odniesienia biblijne w jej Testamencie. Uzasadnia również aktualność wskazań Matki Ledóchowskiej dotyczących Pisma Świętego.

\section{Wartość Pisma Świętego według św. Urszuli na podstawie Rozmyślań}

Najbardziej znaczącym źródłem, świadczącym o wartości Pisma Świętego dla założycielki Zgromadzenia Sióstr Urszulanek Serca Jezusa Konającego, jest książka Rozmyślania. Rozważania znajdujące się w niej opierają się na podanych fragmentach Ewangelii. „Ewangelia jest źródłem niewyczerpanym dla dusz dobrej woli”4 - stwierdza Matka Ledóchowska, która uważa rozmyślanie za najważniejszą podstawę i fundament życia duszy5.

\subsection{O Rozmyślaniach}

Rozmyślania są zbiorem rozważań odnoszących się do poszczególnych perykop ewangelicznych. W znacznej mierze opierają się na Ewangelii, ale zawierają także odniesienia do innych tekstów Pisma Świętego, również do Starego Testamentu. Stanowią przede wszystkim owoc osobistych medytacji św. Urszuli nad Ewangelią. Obejmują nie tylko przemyślenia dotyczące danego fragmentu, ale również modlitewne zwroty skierowane do Boga, do Chrystusa, Matki Bożej i świętych. Zgodnie z zamysłem św. Urszuli Rozmyślania są książką na wskroś praktyczną, przeznaczoną do systematycznego, codziennego użytku; adresowane są do sióstr urszulanek.

W Przedmowie Matka Ledóchowska wyjaśnia, czym są Rozmyślania i w jaki sposób się zrodziły. Święta Urszula ma świadomość posłannictwa zleconego jej przez Boga - wyznaje, że Pan Bóg, mimo jej woli, powierzył jej zadanie nadawania ducha młodej gałęzi urszulańskiej, dlatego jako swój obowiązek traktuje ona uczynienie wszystkiego, co w jej mocy, by „utrwalić to, co zaczęte [...] według woli Bożej i na chwałę Bożą". Święta Urszula zwraca uwagę na to, że duch Zgromadzenia znajduje się Konstytucjach aprobowanych przez Kościół święty, w Dyrektorium, w Zwyczajach. Uważa te dokumenty i pisma za kluczowe. Równocześnie jednak — jako prawdziwa duchowa matka — nosi w sobie pragnienie, aby pozostawić swym córkom coś jeszcze, coś więcej. Właśnie w ten

\footnotetext{
${ }^{4}$ U. Ledóchowska, Rozmyślania dla Sióstr Urszulanek Serca Jezusa Konającego, t. 1, Pniewy

${ }^{5}$ Zob. taż, Pisma zakonne, Pniewy 2000, s. 83.

${ }^{6}$ Taż, Rozmyślania ..., t. 1, s. 5.
} 2000, s. 9 . 
sposób powstały Rozmyślania, napisane po to, aby posłużyły zjednoczeniu serc i ,ujednostajnieniu ducha"7 sióstr rozsianych po różnych wspólnotach i domach Zgromadzenia.

Święta Urszula zachęca, aby uczynić z Rozmyślań stały punkt odniesienia, i podaje powód, dla którego warto tak postąpić. Pisze, zwracając się do siostry: „trzymaj się tych medytacji, które wprowadzą Cię w ducha naszej Kongregacji”». Zasadnicza wartość Rozmyślań zasadza się na tym, że ukazują one duchowy rys Zgromadzenia, wytyczają wewnętrzną drogę pielgrzymowania, którą powinna podążać każda $\mathrm{z}$ sióstr, utożsamiając się $\mathrm{z}$ duchowymi dążeniami i przesłaniem św. Urszuli. Według Założycielki Rozmyślania są ponadto znakiem jedności Zgromadzenia i elementem łączącym siostry na drodze do świętości. „Te nasze rozmyślania - jaki to łącznik miłości siostrzanej w Bogu"g — zauważa Święta. Dostrzega zawarty w rozważaniach określony kierunek wyznaczany siostrom urszulankom Serca Jezusa Konającego, dlatego pisze: „nie szukaj nowych, odrębnych dróg - jedna droga dla wszystkich to zarazem rękojmia prawidłowego rozwoju Zgromadzenia" ${ }^{10}$. Rozmyślania stanowią również pewnego rodzaju obiektywizację, jaką niesie z sobą rozważanie słowa Bożego, które jest żywe, skuteczne, ostrzejsze niż wszelki miecz obosieczny, przenikające aż do rozdzielenia duszy i ducha, stawów i szpiku, zdolne osądzić pragnienia i myśli serca (zob. Hbr 4,12).

Matka Urszula zwraca się do swych duchowych córek:

serdecznie Was proszę, dzieci moje, przyjmijcie te rozmyślania, nad którymi Matuchna Wasza całym sercem pracowała, tym samym sercem, jakim ona Wam je daje. Trzymajcie się ich wiernie. Aby się Wam nie sprzykrzyły, oparłam prawie wszystkie na Ewangelii, która nigdy sprzykrzyć się nie może. [...] Nie mów, że nudno co roku wracać do tego samego rozmyślania — przecież i Kościół co roku wraca do tych samych niedzielnych Ewangelii, do tych samych modlitw podczas Mszy świętej, do tych samych psalmów w brewiarzu. Właśnie to, że co roku wracać będziesz do tych samych rozmyślań, utrwalać Cię będzie w duchu naszym. $Z$ roku na rok będziesz mogła śledzić, czy idziesz naprzód po drodze wytkniętej Ci od samego początku życia zakonnego ${ }^{11}$.

Matka Ledóchowska od początku podaje więc słowa zachęty i wyjaśnienia, zwłaszcza dla tych, którzy byliby nieufnie czy sceptycznie nastawieni do Rozmyślań.

\footnotetext{
7 Tamże.

8 Tamże, s. 6.

9 Tamże.

10 Tamże.

11 Tamże.
} 
Święta Urszula określa jedynie pomocniczą rolę Rozmyślań w stosunku do Ewangelii, do Pisma Świętego. Nadrzędne jest słowo Boże, a Rozmyślania mają służyć tylko wsparciem w modlitwie, w rozważaniu fragmentów Ewangelii. Matka Ledóchowska w żaden sposób nie absolutyzuje tekstów Rozmyślań, przeciwnie - przewiduje sytuacje, gdy komuś jej rozważania nie okażą się pomocne. Zaleca: ,przeczytaj, duszo, treść rozmyślania, a jeśli Ci nie odpowiada, szukaj dla siebie pokarmu w podanym ustępie Ewangelii"'2. Tekst Pisma Świętego jest dla św. Urszuli zawsze na pierwszym miejscu, a wszelkie inne ludzkie słowa są jedynie drugorzędne i stanowią komentarz do tekstu natchnionego. Matka Ledóchowska ma świadomość, że Pan Bóg prowadzi ludzi różnymi drogami i naiwnością byłoby chcieć wtłoczyć wszystkich w jeden schemat - takie postępowanie nie dawałoby prymatu Duchowi Świętemu, który jest pierwszym prowadzącym wierzącego na drodze duchowego wzrostu. Autorka Rozmyślań, będąc osobą o szerokich horyzontach, wolną od ciasnoty i schematyzmu, zaznacza, zwracając się do siostry:

Może Bóg duszę Twą poprowadzi wyższą drogą — kontemplacji, wtedy poddawaj się prowadzeniu Bożemu, ale jeśli Cię zostawi na zwykłej drodze często mozolnego rozmyślania opartego na pracy trzech władz duszy: rozumu, serca i woli - trzymaj się tych medytacji1 ${ }^{13}$.

Według Matki Ledóchowskiej rozmyślania przygotowane są w taki sposób, aby mogła się nimi posłużyć każda siostra, niezależnie od wieku, wykształcenia, pochodzenia czy pełnionych obowiązków.

Matka Ledóchowska pozostawia więc swym duchowym córkom pomoc w porannej medytacji na wszystkie dni roku. Tym samym wytycza program systematycznej, uporządkowanej pracy duchowej. Zgodnie z zamysłem Świętej Rozmyślania mają pomagać w rozważaniu Ewangelii, która jest miejscem spotkania z Chrystusem. Rozmyślania nie stanowią natomiast opracowania z dziedziny egzegezy biblijnej. Założycielka Zgromadzenia Sióstr Urszulanek Serca Jezusa Konającego nie była badaczką Pisma Świętego, nie sięgała do wówczas wypracowanych metod analizy Biblii, lecz reprezentowała podejście praktyczne. Wojciech Misztal zauważa, że właśnie takie podejście dało początek Pismu Świętemu, które powstało, by karmić, pielęgnować i rozwijać duchowośćc ${ }^{14}$ - w tym celu Biblia powinna być czytana, rozważana i wyjaśniana z wykorzystaniem osiągnięć egzegezy.

12 Tamże.

13 Tamże.

14 Zob. W. Misztal, Ewangelia w duchowości św. Urszuli [w:] „, Otrzymała od Ducha Świętego wielki charyzmat”. Św. Urszula Ledóchowska i Urszulanki Serca Jezusa Konającego, red. M. Krupecka, W. Misztal, Kraków 2012, s. 128. 


\section{2. Święta Urszula o Ewangelii}

Zapisy rozważań św. Urszuli opartych na Ewangelii są świadectwem umiłowania słowa Bożego. Matka Ledóchowska zwraca uwagę na wielki szacunek, jaki żydzi mieli do Pisma Świętego i w tym kontekście zauważa, że chrześcijanie mają nie tylko słowa proroków, ale słowo samego Syna Bożego ${ }^{15}$. Dla autorki Rozmyślań Ewangelia jest miejscem spotkania z żywym słowem Bożym, ze Słowem Wcielonym, z Chrystusem - pozwala spotykać prawdziwego Jezusa, poznawać Go, napełniać się Duchem Bożym. Czytanie jej i rozważanie ma prowadzić — zdaniem św. Urszuli — do głębszej miłości i zażyłości z Jezusem. Matka pisze, wzywając i zachęcając siostry do umiłowania Ewangelii:

O, żebyśmy umiały przez częste jej czytanie wyrobić sobie taki jasny obraz Chrystusa, by Jego Boska postać towarzyszyła nam zawsze; żebyśmy w każdej niepewności umiały podnosić oczy do tego naszego Wodza i w przykładzie Jego życia szukać wskazówek co do naszego postępowania! ${ }^{16}$.

Bliska więź z Chrystusem, budowana na rozważaniu wydarzeń z Jego życia, ma znaleźć odzwierciedlenie w codziennej egzystencji człowieka wierzącego.

Ewangelia daje więc przede wszystkim poznanie Osoby Jezusa Chrystusa. Święta Urszula poleca siostrom stawiać sobie pytanie: ,czy ja Go poznałam i czy czynię wszystko, co jest w mojej mocy, by Go poznać i by inni Go poznali? Poznać Jezusa mogę przez poważne czytanie Ewangelii, przez rozmyślanie, przez zastanawianie się nad Jego nauką, Jego zasadami, przez pełne miłości zbliżanie się do Niego"17. Głębsze poznanie Zbawiciela i wejście w relację z Nim nie może dokonać się z pominięciem Ewangelii. Ponadto niezbędne jest nie tylko czytanie słowa Bożego, lecz także medytacja, modlitwa tym słowem, połączona z pragnieniem głębszego poznania Pana, płynącego z miłości ku Niemu. Matka Ledóchowska zapewnia: „wszak On — Przyjaciel mój najlepszy, pełen dla mnie słodyczy, łaskawości”"18. I dodaje: ,jeżeli daleko się od Niego trzymam, to dlatego, że Go nie znam, że nie zdaję sobie dość sprawy z tej nieskończonej Jego ku mnie miłości"19. Zaleca prosić Chrystusa o łaskę poznania Go i Jego miłość.

Według autorki Rozmyślań każdy chrześcijanin powinien wkładać wysiłek woli i umysłu, aby stopniowo i systematycznie poznawać Pana Jezusa i upodabniać się do Niego: „cudowna postaci Chrystusa, muszę usilną pracą jakby od-

\footnotetext{
15 Zob. U. Ledóchowska, Rozmyślania ..., t. 1, I. 12.

16 Tamże.

17 Tamże, XII. 3.

18 Tamże.

19 Tamże.
} 
tworzyć dla siebie Twój obraz"20. Osoba zakonna jest powołana do szczególnego naśladowania Chrystusa przez praktykę rad ewangelicznych: czystości, ubóstwa i posłuszeństwa. Rozważanie Ewangelii jest niezbędne do tego, aby autentycznie żyć ślubami zakonnymi. Dlatego św. Urszula kieruje do każdej siostry słowa: „muszę coraz uważniej wpatrywać się w cnoty Jezusa, coraz bardziej zżywać się z Nim, żyć Jego życiem, trzymać się Jego, być przy Nim, by Go naśladować, razem z Nim myśleć, mówić, działać, modlić się i cierpieć" ${ }^{21}$. Zapewnia, że życie w towarzystwie Pana jest słodkie.

Medytacja i kontemplacja Osoby Zbawiciela prowadzi do tego, żeby w doświadczanych brakach, ubóstwie, niewygodach, wyczerpaniu umieć kierować serce i wzrok do Chrystusa, który cierpi ubóstwo w stajence betlejemskiej, który jest spracowany i zmęczony, gdy podejmuje trud pracy fizycznej w Nazarecie. Natomiast chwile radości nie mogą być zapominaniem o Zbawicielu, przeciwnie - powinny być sposobnością do wchodzenia w podobne sceny ewangeliczne, na przykład do patrzenia na Jezusa podczas wesela w Kanie Galilejskiej i dzielenia z Nim Jego radości. Podobnie św. Urszula zwraca się do Pana, prosząc Go:

Niech pola pokryte zbożem przypominają mi Twe współczucie dla ludu zostawionego jak owce bez pasterza i Twą zachętę, by modlić się o robotników dla żniwa Bożego. Wody jeziora - Ciebie uczącego z łodzi rzesze stojące nad brzegiem. Burze i wichry - Twą Boską potęgę, która uciszyła wzburzone żywioły. Gdy na mnie spadną krzyże i cierpienia, niech widzę Ciebie smutnego aż do śmierci, pocącego się krwią w Ogrójcu, Ciebie ukoronowanego cierniem, oblanego krwią przy kolumnie biczowania. $\mathrm{W}$ upokorzeniu - Ciebie, Panie, na pośmiewisko królem nazwanego, przez Heroda wyśmianego i spoliczkowanego. W troskach i prześladowaniu — Ciebie krzyż dźwigającego, na krzyżu umierającego ${ }^{22}$.

Modlitwa ta pokazuje, jak kluczowe znaczenie ma dla św. Urszuli Ewangelia, zdolność jej rozważania i odniesienia do własnego życia. Pochylanie się nad słowem Bożym nie jest dla Matki Ledóchowskiej jedną z wielu praktyk, do której jest się zobowiązanym na drodze życia zakonnego. Zdolność wytrwałego i systematycznego zatrzymywania się nad Ewangelią i wczytywania się w nią, to pragnienie serca, które chce coraz bardziej przylgnąć do Zbawiciela. „Jakże powinniśmy cenić, kochać Ewangelię!"23 — zaznacza św. Urszula.

Autorka Rozmyślań zachęca, by słowa Chrystusa przyjmować z wiarą i największą miłością, tak aby je zachowywać jako skarb. „Czyż nie mam Ewangelii,

\footnotetext{
20 Tamże, I. 12.

21 Tamże, II. 17.

22 Tamże, I. 12.

23 Tamże.
} 
która mi powtarza Jego słowa i stawia przed oczyma Jego czyny?’24 — pyta retorycznie św. Urszula i dodaje, że Jezus nie przemawia obecnie jak podczas swego ziemskiego życia w Palestynie, jednak nie przeszkadza to temu, aby — czytając w Piśmie Świętym Jego naukę — w duchu przyłączyć się do słuchających Chrystusa. Matka Ledóchowska poleca pytać siostrom same siebie: „czy cenię Ewangelię? Czy chętnie i z miłością ją czytam? A przez uważne jej czytanie czy coraz bardziej zbliżam się do Jezusa i coraz więcej Go kocham?"25. Pytania te zarazem odnoszą się do tego, co podstawowe w życiu zakonnym, które jest drogą bliższego naśladowania Chrystusa. Święta Urszula przekonuje więc o niezastąpionej roli Ewangelii: „o, żebym zrozumiała, czym jest dla mnie Ewangelia i czym być może, gdybym chciała ją studiować, czytać, rozmyślać nad nią!"26. Dlatego tak niezbędne jest, aby pokonywać i usuwać wszelkie przeszkody, zwłaszcza: znużenie, nudę, zniechęcenie - stające przed człowiekiem, któremu wydaje się, że już zna treść Ewangelii - i ciągle wracać do słowa Bożego. Aby ukazać wartość Pisma Świętego, Matka Urszula posługuje się metaforą skarbu, do którego trzeba się niekiedy dokopywać z mozołem, szukając go nieraz długo i wśród przeciwności, ale znalezienie go przynosi wielkie szczęście ${ }^{27}$.

Matka Ledóchowska wskazuje na to, że przez stałe wczytywanie się w Ewangelię możliwe jest niejako prowadzenie takiego życia, które było udziałem apostołów, a realizuje się ono, gdy wierzący myślą, sercem i duszą trwa w towarzystwie i obecności Pana.

Życie moje wówczas zamieniłoby się na życie nieziemskie - na ziemi, ale nie z tej ziemi; na życie Boże, bo na wzór życia Jezusa prowadzone, ożywione nie duchem świata, ale zupełnie przesiąknięte duchem Jezusa. Jezus stałby się mym towarzyszem, mym przyjacielem, do którego ciągle miałabym oczy skierowane, z którym ciągle rozmawiałabym, którego radziłabym się, u którego zawsze znalazłabym pociechę, uspokojenie i promyk nadziei w chwilach ciężkich, czarnych, których nie brak w życiu!28

pisze św. Urszula. Równocześnie świadoma pokus, na które mogą napotykać wierzący, poleca siostrom modlić się następującymi słowami:

O Jezu, Ty sam mi dopomagaj, bym stała zawsze przy Tobie przez wierne szukanie Ciebie w czytaniu Ewangelii. Niech mnie nie odciąga od tego moje wrodzone

\footnotetext{
24 Tamże, II. 17.

25 Tamże.

26 Tamże.

27 Zob. tamże.

28 Tamże.
} 
lenistwo, a wrodzona ciekawość nie prowadzi do czytania wielu innych książek z zaniedbaniem Ewangeliii ${ }^{29}$.

Według św. Urszuli Ewangelia to życiowy drogowskaz, który nie pozwala się zagubić w zmaganiach. „Tam mamy wskazówki, jak postępować w każdej okoliczności życia"30 — zapewnia Matka. Słowo Boże daje nie tyle gotowe rozwiązania problemów, ile pozwala właściwie kształtować rozum, wolę i uczucia. Autorka Rozmyślań pisze o Ewangelii: „ona jest dla mnie jasnym promieniem przedzierającym się z nieba do duszy mojej, ona rozpędza ciemności mego umysłu, wskazuje mi, jaką mam iść drogą. Ona jest iskrą świętą, która rozpala w sercu moim ogień świętej miłości”31. Dlatego prosi Pana: „o Jezu, niech me serce lgnie do Twej świętej nauki, niech nieustannie szukam światła w Ewangelii, niech giętkim umysłem poddaję się wszelkim prawom Bożym, choć zrozumieć ich nie moge" 32 . Rozważanie słowa Bożego pozwala właściwie spoglądać na świat, patrząc oczami wiary i umacniać miłość.

O Jezu, niech Ewangelia Twoja staje się dla mnie drogowskazem, wierną przyjaciółką każdego dnia, światłością rozpraszającą cienie zwątpienia, smutku, pokus i śmierci. Panie, często, bardzo często przeczytam sobie choć stroniczkę Ewangelii. Niech nie będzie dla mnie piękniejszej książki nad Ciebie, Ewangelio moja! ${ }^{33}$

pisze autorka Rozmyślań. Jest przekonana o ważności i niezastąpionej roli stałego kontaktu ze słowem Bożym. Ten, kto z wiarą przyjmuje słowa Ewangelii, żyje nimi i daje się przeniknąć duchem Ewangelii, może doświadczyć w codzienności jej mocy.

Autorka Rozmyślań ukazuje Jezusa Chrystusa jako Nauczyciela i Mistrza, który podczas swego ziemskiego życia naucza, uzdrawia i głosi królestwo Boże. Zauważa, że również i dzisiaj kieruje On swoje nauczanie i objawia swą wolę na różne sposoby. Jednym z nich jest Ewangelia. Dlatego każe siostrom pytać siebie, zwracając się do Zbawiciela: „czy z [...] miłością, gorliwością przyjmuję Twą naukę, Twe wskazówki, napomnienia, których mi udzielasz bądź przez wewnętrzne natchnienia, bądź przez słowa Ewangelii?"34. Wielokrotnie poleca swoim duchowym córkom, aby z miłości do Ewangelii czyniły przedmiot rachunku sumienia. Zapewnia:

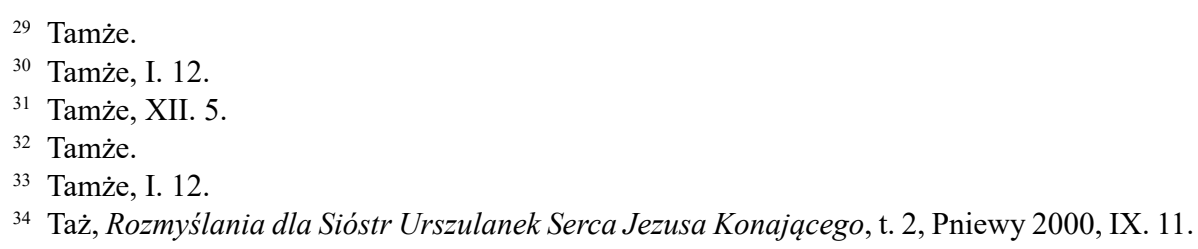


Nigdy dość jej naczytać się nie można — im bardziej tę świętą księgę zgłębiamy, tym bardziej słowa te nabierają siły i tym więcej światła wnoszą do naszej duszy. Ewangelię trzeba kochać, trzeba ciągle ją odczytywać, by ducha Ewangelii, a tym samym i Jezusa w życie swe wprowadzać, a wtedy stanie się ono jasne i święte ${ }^{35}$.

Zachęca, by prosić Pana o umiłowanie słuchania Jego słów, o łaskę wczytywania się w Ewangelię z gorącym pragnieniem wiernego zastosowania się do jej rad i przykazań. „Nie mogę dać Tobie w obecnym moim życiu większego dowodu miłości, jak tylko kochając każde słowo, które z ust Twych wyszło"36 — zwraca się w modlitwie do Pana św. Urszula.

Ewangelia daje możliwość odkrywania i wypełniania woli Bożej.

Jezu, znam Twoją wolę, jest ona dla mnie zawarta w Twych naukach ewangelicznych, w moich Konstytucjach, jest w woli moich przełożonych, w moich obowiązkach. Jednego mi tylko potrzeba — bym nieustannie dążyła do wiernego wykonania Twej woli, tak jasno objawionej. Nie w samych modlitwach, nadzwyczajnych pokutach i cnotach zawiera się moja świętość, ale przede wszystkim w najściślejszym stosowaniu się do woli Bożej ${ }^{37}$

pisze św. Urszula. Pełnienie woli Bożej jest dla niej priorytetem, który wypływa z miłości do Pana Boga.

Umiłowanie Ewangelii i miłość do Chrystusa w Przenajświętszym Sakramencie znajdują się w bezpośrednim związku. Poznanie Osoby Jezusa z Nazaretu przychodzi przez czytanie oraz rozważanie Ewangelii i powinno prowadzić do adoracji Chrystusa obecnego w Najświętszym Sakramencie. „Chcę Cię, Jezu mój, szukać w tej świętej Księdze, a wtedy w Przenajświętszym Sakramencie Ołtarza łatwiej zrozumiem i znajdę Ciebie takiego samego, jakim byłeś w ziemi palestyńskiej. Potrzeba mi Ewangelii, ażeby nauczyć się z całego serca przylgnąć do Jezusa w Tabernakulum"38 — zwraca się do Zbawiciela Urszula, podsuwając tym samym czytelnikowi Rozmyślań słowa osobistej modlitwy. Pokazuje, że ten, kto modli się do Pana obecnego w Eucharystii pod postaciami chleba i wina, spotyka się z Tym, którego poznał przez słowo Boże. „Dusza wierna wszędzie widzi Jezusa, i to jest jej siłą, jej szczęściem. Widzi Go w Tabernakulum, i dlatego szczęściem jej jest klęczeć u stóp ołtarza i oczyma duszy wpatrywać się w tę cudowną postać Jezusa, którą tak dobrze zna przez czytanie Ewangelii" ${ }^{39}$ — stwierdza.

\footnotetext{
35 Taż, Rozmyślania ..., t. 1, XII. 20.

36 Tamże.

37 Taż, Rozmyślania ..., t. 2, IX. 20

38 Taż, Rozmyślania ..., t. 1, II. 17.

39 Tamże, I. 3.
} 


\section{Odniesienia biblijne w Testamencie św. Urszuli}

Wśród pism autorstwa Matki Urszuli Ledóchowskiej znaczące miejsce zajmuje jej Testament, który stanowi duchowe przesłanie. Testament zawiera prośby skierowane do duchowych córek - święta Urszula dokonuje w nim wyboru tego, co najważniejsze; wyróżnia to, na co chce szczególnie zwrócić siostrom uwagę. W kilkunastu prośbach uczula swoje duchowe córki na miłość do Najświętszego Serca Jezusa, do Jezusa Ukrzyżowanego, do Najświętszego Sakramentu; przypomina o znaczeniu pokory, miłości siostrzanej, ubóstwa, posłuszeństwa, modlitwy, nabożeństwa do Matki Najświętszej, umartwienia, pogody ducha, milczenia, skupienia; prosi o wierne spełnianie reguły, szczerość względem przełożonych i szacunek do wszystkich zgromadzeń zakonnych. Poleca siostrom, by były zupełnie złączone z wolą Bożą, by przenikała je gorliwość o zbawienie dusz oraz by były wierne i wytrwałe do końca. W tym duchowym przesłaniu św. Urszuli nie ma oddzielnej prośby, która mówiłaby o umiłowaniu Pisma Świętego czy umiłowaniu Ewangelii. Nie można jednak z tego wnioskować, że Matce Ledóchowskiej ta sprawa nie leży na sercu. Według niej miłość do słowa Bożego musi charakteryzować każdą siostrę urszulankę, co niejednokrotnie zaznacza zwłaszcza w Rozmyślaniach. Co więcej, warto zwrócić uwagę na to, że choć Matka nie poświęca explicite oddzielnej prośby tematowi Ewangelii, to cały Testament wzywa implicite do słuchania i wypełniania słowa Bożego, gdyż jest przeniknięty tym słowem. Święta Urszula w Testamencie wielokrotnie cytuje i przywołuje słowa Pisma Świętego, zwłaszcza Ewangelię. Te wybrane przez Matkę Ledóchowską cytaty z Biblii dobrze obrazują istotne elementy duchowości przez nią pozostawionej.

Pierwszy i ostatni spośród kilkunastu cytowanych przez św. Urszulę w Testamencie fragmentów biblijnych mają wspólny mianownik: mówią o królestwie Bożym. Ciąg cytatów rozpoczynają słowa umocnienia, będące zachętą do zaufania Bogu: „nie bój się, mała trzódko, gdyż spodobało się Ojcu waszemu dać wam królestwo" (Łk 12,32), a zakończenie Testamentu zatytułowane Ostatnie me stowa do moich drogich dzieci zawiera wezwanie: „starajcie się najpierw o królestwo Boga i Jego sprawiedliwość" (Mt 6,33). Urszula wskazuje siostrom, że królestwo Boskiego Serca jest ich udziałem, a rozszerzanie panowania Zbawiciela w duszach ludzkich powinno być ich troską i zadaniem ${ }^{40}$.

Jedyne zdanie biblijne, które w Testamencie cytowane jest aż dwukrotnie, to ewangeliczne zapewnienie Mistrza z Nazaretu dotyczące jedności pomiędzy miłością Chrystusa i miłością bliźniego: „wszystko, co uczyniliście jednemu z tych braci moich najmniejszych, Mnieście uczynili” (Mt 25,40), znajdujące się w Prośbach III i IV. Święta Urszula wyraźnie zaznacza, że miłość do Boga musi

${ }^{40}$ Zob. taż, Pisma ..., s. 13. 
się odzwierciedlać w czynach miłości wobec braci i sióstr. Powołaniem urszulanki jest być pociechą dla Chrystusa, dla Jego Konającego Serca. To zadanie zostaje wypełnione, gdy żyje się dla szczęścia innych, w miłości bliźniego, w poświęceniu dla drugiego, zapominając o sobie. Matka Ledóchowska zachęca do gotowości do najmniejszego choćby uczynku miłości, która jest owocem codziennego postanowienia dawanego na modlitwie Chrystusowi u stóp krzyża: „konające Serce Jezusa, chcę pocieszyć Ciebie, dając szczęście siostrom moim!’’1. Ewangeliczne zdanie akcentowane przez św. Urszulę w Testamencie: „wszystko, co uczyniliście jednemu z tych braci moich najmniejszych, Mnieście uczynili” (Mt 25,40) powinno również być wezwaniem do gorliwej służby innym i ofiarnej pracy. Czyny dobroci i miłosierdzia spełniane dla drugich są wyrazem miłości do Chrystusa. Autorka Testamentu stawia siostrom retoryczne pytanie: „czyż ta myśl, że pracując na utrzymanie naszych sierot, pracujemy dla Jezusa samego, nie będzie dla Was zachętą do coraz gorliwszej pracy, do poświęcenia bez granic w pracach Waszych?" ‘2. Tym samym uwidacznia się, w jaki sposób św. Urszula zwraca uwagę na najgłębszą motywację podejmowanych działań.

Powyżej omawiane zdanie ewangeliczne (Mt 25,40) nie jest jedynym fragmentem Pisma Świętego mówiącym o miłości cytowanym przez Matkę Urszulę w Testamencie. Przytacza ona również (w Prośbie III) nowe przykazanie miłości zapisane w Ewangelii według św. Jana: „przykazanie nowe daję wam, abyście się wzajemnie miłowali tak, jak Ja was umiłowałem; żebyście i wy tak się miłowali wzajemnie. Po tym wszyscy poznają, żeście uczniami moimi, jeśli będziecie się wzajemnie miłowali” (J 13,34-35). Pokazuje to jednoznacznie, jak dogłębnie Święta rozpoznaje i rozumie istotę miłości chrześcijańskiej. Ponadto poleca siostrom często rozważać te słowa, aby według nich postępować oraz wpatrywać się we wzór ofiarnej i pełnej poświecenia miłości, jaki daje Zbawiciel ${ }^{43}$.

Kolejnym zdaniem ewangelicznym przytoczonym przez św. Urszulę w jej duchowym przesłaniu jest hasło Zgromadzenia Sióstr Urszulanek Serca Jezusa Konającego: „oto ja służebnica Pańska, niech mi się stanie według słowa Twego" (Łk 1,38). Słowa te wyrażają maryjny rys duchowości pozostawionej przez Matkę Ledóchowską. Wskazuje ona na niezastąpioną wartość postawy gotowości wypełnienia woli Bożej na wzór Matki Najświętszej. Autorka Testamentu przekonuje ponadto: „bądźcie pewne, że Maryja raczej cudem przyjdzie Wam z pomocą, niż miałaby Was opuścić" "44; zachęca, by z dziecięcą ufnością uciekać się do Matki Zbawiciela oraz naśladować Ją w rozeznawaniu i przyjmowaniu zamysłów Bożych.

\footnotetext{
41 Tamże, s. 21.

42 Tamże, s. 25.

43 Zob. tamże, s. 19.

44 Tamże, s. 39.
} 
Znaczenie wiernego wypełniania woli Bożej w życiu zakonnym jest przez św. Urszulę wielokrotnie akcentowane w omawianym tekście. Podkreśla ona szczęście płynące z takiej postawy; człowiek może wtedy w pokoju serca powiedzieć: „żyję ja — już nie ja, nie moja, ale wola Boża — ale Chrystus"45 — zaznacza autorka Testamentu, parafrazując tym samym słowa z Listu św. Pawła Apostoła do Galatów (zob. Ga 2,20). O pełnieniu woli Bożej mówi również inne zdanie św. Pawła cytowane przez św. Urszulę w Prośbie XII: „wolą Bożą jest wasze uświęcenie" (1 Tes 4,3). Temat odczytywania i realizacji Bożych zamiarów ma bowiem dla Matki Ledóchowskiej fundamentalne znaczenie.

Kolejne trzy cytaty (jeden ze Starego i dwa z Nowego Testamentu) dotykają tajemnicy Chrystusa oddającego życie w ofierze z samego siebie na Krzyżu. Prośbę VII mówiącą o miłości do Jezusa Ukrzyżowanego Matka Urszula rozpoczyna od przytoczenia słów św. Pawła z Listu do Galatów: „co do mnie, nie daj Boże, bym się miał chlubić z czego innego, jak tylko z krzyża Pana naszego Jezusa Chrystusa, dzięki któremu świat stał się ukrzyżowany dla mnie, a ja dla świata" (Ga 6,14). Zgodnie z zamysłem Założycielki nabożeństwo do Chrystusa Ukrzyżowanego zajmuje centralne miejsce w duchowości sióstr urszulanek. W tym też kontekście św. Urszula przytacza i akcentuje słowo „pragnę” $(J 19,28)$ wypowiedziane przez Zbawiciela z wysokości Krzyża. Ukazuje, że nie wyraża ono jedynie pragnienia fizycznego, lecz jest to wołanie o miłość. Dlatego Matka Ledóchowska zaleca wsłuchiwać się w bolesną skargę konającego Pana w tym celu cytuje zdanie z Księgi Psalmów, które interpretuje jako słowa Chrystusa: „na współczującego czekałem, ale go nie było, i na pocieszających, lecz nie znalazłem" (Ps 69,21).

Pozostałe dwa cytaty ewangeliczne umieszczone przez św. Urszulę w jej Testamencie stanowią przypomnienie zachęty kierowania do Boga próśb, z wiarą i ufnością: „proście, a będzie wam dane” (Mt 7,7) oraz mówią o konieczności wytrwałości: „kto wytrwa do końca, ten będzie zbawiony” (Mt 10,22). Wszystkie wybrane i przytoczone przez Matkę Ledóchowską fragmenty biblijne pokazują, jak rozkładają się akcenty w jej duchowości.

\section{Aktualność wskazań św. Urszuli dotyczących Pisma Świętego}

Zgodnie z nauczaniem Vaticanum II Pismo Święte powinno być rzeczywistym źródłem duchowości chrześcijańskiej ${ }^{46}$. Prawdę tę podkreśla Konstytucja dogmatyczna o Objawieniu Bożym Dei Verbum. Ewangelia ma znajdować swoje

45 Tamże, s. 53.

46 Zob. Sobór Watykański II, Konstytucja dogmatyczna o Objawieniu Bożym „Dei Verbum”, Poznań 2002, nr 21. 
urzeczywistnienie w życiu każdego chrześcijanina. Słowo Boże powinno być dla wierzącego istotną przestrzenią do uczenia się bliskiej relacji z Bogiem. Rozważanie Pisma Świętego stwarza i umacnia osobistą więź z żywym Bogiem i uzdalnia do rozeznawania i wypełniania Jego zbawczej woli. Posoborowe nauczanie Kościoła potwierdza i rozwija treści zawarte w konstytucji Dei Verbum. Święty Jan Paweł II w adhortacji Vita consecrata stwierdza jednoznacznie: ,słowo Boże jest pierwszym źródłem wszelkiej duchowości chrześcijańskiej” ${ }^{47}$. Podobnie zaznacza papież Benedykt XVI w adhortacji Verbum Domini: „słowo Boże leży u podstaw każdej autentycznej duchowości chrześcijańskiej” ${ }^{48}$.

Słowo Boże ma niezastąpioną wartość dla życia duchowego człowieka, ponieważ zawiera jednocześnie: obiektywne ukazanie zbawczego planu Boga, opis życia wierzącego - odpowiedź wierzącego na Objawienie oraz doświadczenia, w których chrześcijanin może uczestniczyć przez wiarę i dzięki Duchowi Świętemu działającemu w Kościele. II Sobór Watykański w Konstytucji dogmatycznej o Objawieniu Bożym Dei Verbum stwierdza, że „...tak wielka tkwi w słowie Bożym moc i potęga, że jest ono dla Kościoła podporą i siłą żywotną, a dla synów Kościoła utwierdzeniem wiary, pokarmem duszy oraz źródłem czystym i stałym życia duchowego" ${ }^{49}$, natomiast studium Pisma Świętego uznaje za duszę teologii ${ }^{50}$. Pismo Święte zawiera słowo Boże, jego Autorem jest Duch Święty, który działał przez autorów ludzkich ${ }^{51}$. Biblia opisuje doświadczenie wiary. Dzięki Duchowi Świętemu i za sprawą wiary człowiek może uczestniczyć w doświadczeniach, które są opisane w Piśmie Świętym. Wiara rodzi się ze słuchania słowa Bożego.

Chrześcijaństwo nie jest jednak religią Księgi — jest religią Osoby, Słowa Wcielonego i żywego, religią słowa Bożego, a nie słowa spisanego i milczącego $^{52}$. Biblia nie stoi u początku chrześcijaństwa, lecz jest wtórna względem doświadczenia wiary. Pismo Święte jest mową Bożą, utrwaloną pod natchnieniem Ducha Świętego na piśmie ${ }^{53}$. Jest zarazem „opowieścią” o tym, co Bóg uczynił dla ludzi, ukazuje realizację zbawczego planu Miłości Boga — daje się On poznać przez swoje działanie. Bóg, zstępując w swej dobroci, by objawić się człowiekowi, przemawia ludzkimi słowami. „Przez wszystkie słowa Pisma Świętego Bóg wypowiada tylko jedno Słowo, swoje jedyne Słowo, w którym

47 Jan Paweł II, Adhortacja ,, Vita consecrata”, Watykan 1996, nr 94.

${ }^{48}$ Benedykt XVI, Adhortacja ,, Verbum Domini”, Watykan 2010, nr 86.

${ }^{49}$ Sobór Watykański II, Konstytucja..., nr 21; zob. także: Katechizm Kościoła katolickiego, Poznań 1994 [dalej: KKK], nr 131.

${ }^{50}$ Zob. Sobór Watykański II, Konstytucja..., nr 24.

${ }^{51}$ Zob. KKK 136.

${ }_{52}$ Zob. Benedykt XVI, Adhortacja ..., nr 7; KKK 108.

${ }^{53}$ Zob. KKK 81. 
wypowiada się cały"54. Całe Pismo Święte wypełnia się w Chrystusie ${ }^{55}$. On jest jedynym Słowem Pisma Świętego. Kościół zachęca wiernych, aby przez częste czytanie słowa Bożego dochodzili do znajomości Jezusa Chrystusa ${ }^{56}$. Znajomość Jezusa nie oznacza jednak tylko poznania intelektualnego, ale musi być osobistą odpowiedzią człowieka na zaproszenie Chrystusa. W Piśmie Świętym znajduje się pokarm i moc ${ }^{57}$. Katechizm Kościoła katolickiego zaznacza, że Pismo Święte i Ciało Pańskie karmią całe życie chrześcijańskie i nim kierują ${ }^{58}$.

Takie właśnie podejście do Pisma Świętego było bliskie Matce Urszuli, która zawsze pochylała się nad słowem Bożym z wiarą. Zachęcała szczególnie do rozważania i kontemplacji Ewangelii, ponieważ ona pozwala lepiej poznać Osobę Jezusa Chrystusa i pogłębiać z Nim więź. Czytanie i medytacja Biblii w duchu wiary były dla świętej Urszuli niezbędnym elementem życia duchowego. Matka Ledóchowska podkreślała również wyraźny związek słowa Bożego i Eucharystii, o którym mówi także Katechizm Kościoła katolickiego.

„Tekst biblijny może właściwie zrozumieć tylko ten, kto sam przeżył to, o czym mówi tekst" ${ }^{\prime 9}$ - stwierdza dokument Papieskiej Komisji Biblijnej Interpretacja Pisma Świętego w Kościele. Nie można zrozumieć Pisma Świętego, jeśli nie ma się wewnętrznego doświadczenia działania Boga we własnym życiu. Życie duchowe i hermeneutyka Pisma są ze sobą ściśle powiązane ${ }^{60}$. „W miarę jak umacnia się życie Duchem Świętym czytelnika tekstów natchnionych, pogłębia się też zrozumienie rzeczywistości, o której mówią teksty" ${ }^{61}$. Życie św. Urszuli jest doskonałym przykładem stopniowego wnikania w głębię słowa Bożego, płynącego z doświadczenia wiary i z gotowości na przyjęcie Bożego prowadzenia na drogach codzienności.

Słowo Boże zawarte w Piśmie Świętym jest bezpośrednim zaproszeniem do dialogu z Bogiem; pobudza do odpowiedzi Bogu, która jest szczególnie znacząca dla życia duchowego ${ }^{62}$. Richard Rohr zauważa, że „,...geniusz objawienia biblijnego polega na tym, że nie podsuwa nam ono rozwiązań, lecz (1) otwiera przed nami drogę, którą do nich dochodzimy, i (2) oferuje wewnętrzny i zewnętrzny autorytet, który pozwala nam tej drodze zaufać" ${ }^{63}$. Orędzie biblijne zawiera istotę

${ }^{54}$ Tamże 102.

${ }^{55}$ Zob. tamże 134.

${ }^{56}$ Zob. Sobór Watykański II, Konstytucja..., nr 25.

${ }^{57}$ Zob. tamże, nr 24.

${ }^{58}$ Zob. KKK 141.

${ }_{59}$ Papieska Komisja Biblijna, Interpretacja Pisma Świętego w Kościele, Watykan 1993, II, A, 2.

${ }^{60}$ Zob. Benedykt XVI, Adhortacja..., nr 30.

${ }^{61}$ Papieska Komisja Biblijna, Interpretacja..., II, A, 2.

${ }^{62}$ Zob. Ch.A. Bernard, Wprowadzenie do teologii duchowości, thum. J. Machniak, Kraków 1996, s. 50.

${ }^{63}$ R. Rohr, Rzeczy ukryte. Odkrywanie duchowości Pisma, thum. M. Chojnacki, Kraków 2015, s. 23. 
tajemnicy wiary, którą człowiek wierzący powinien przyjąć w sposób osobisty. Pismo Święte zawiera klucz do odczytania wydarzeń relacji między Bogiem, Panem świata, a ludźmi wszystkich czasów - historii stworzenia i odkupienia od grzechu. Skłania do refleksji na temat stosunku wiary do innych aspektów życia $^{64}$. Święta Urszula Ledóchowska jest tą, która pozwoliła kształtować się słowu Bożemu. Jej pisma pokazują, w jaki sposób rozumiała Biblię i jakie ona miała dla niej znaczenie; jej życie zaś nie tylko świadczy o umiłowaniu Ewangelii, lecz także stanowi żywą egzegezę słów Chrystusa.

„Najgłębsza interpretacja Pisma pochodzi od tych, którzy pozwolili się kształtować słowu Bożemu przez słuchanie go, czytanie i wytrwałe rozważanie" ${ }^{95}$ stwierdza Benedykt XVI w adhortacji Verbum Domini. Święci Kościoła katolickiego - a wśród nich również św. Urszula Ledóchowska - to osoby, które żyły słowem Bożym; Pismo Święte było dla nich podstawowym odniesieniem. Co więcej, bez nich interpretacja Biblii nie byłaby pełna ${ }^{66}$. „Każdy święty jest jakby promieniem światła wychodzącym ze słowa Bożego" ${ }^{67}$. Święci ukazują prawdziwe oblicze Boga i człowieka ${ }^{68}$. Hans Urs von Balthasar jest zdania, że życie świętych to dogmatyka doświadczalna ${ }^{69}$.

Pismo Święte jest źródłem duchowości chrześcijańskiej, choć nie jedynym ${ }^{70}$. Duchowość chrześcijańska dotyczy życia chrześcijańskiego, o ile jest ono projektem osobowym, odnoszącym się do świadomego zaangażowania człowieka ${ }^{71}$. W dzisiejszym świecie człowiek znajduje się pod silnym działaniem i wpływem czynników, które go spychają z drogi prowadzącej ku wewnątrz, z drogi zasłuchania i głębszego namysłu, a skłaniają do życia na zewnątrz, do karmienia się tym, co powierzchowne. Ludzie, którzy pozwalają, by wciągnął ich życiowy wir, gubią samych siebie ${ }^{72}$. Nie brakuje jednak takich, którzy chcą podejmować

${ }^{64}$ Zob. F.R. de Gasperis, Biblia — droga do Życia, thum. A. Koprowski, Warszawa 2018, s. $8-10$.

65 Benedykt XVI, Adhortacja..., nr 48.

66 Zob. tamże.

67 Tamże.

68 Zob. Benedykt XVI, Rozważanie przed modlitwa Anioł Pański: Święci ukazują prawdziwe oblicze Boga i człowieka, 9 VIII 2009, „L'Osservatore Romano” (wydanie polskie), 10 (2009), s. 41.

69 Zob. R. Skrzypczak, Wstęp [w:] J. Bątkiewicz-Brożek, Jezu, Ty się tym zajmij!, Kraków 2017, s. 21.

${ }^{70}$ Za źródła teologii duchowości uznaje się: Pismo Święte, historię duchowości, doświadczenie osobowe, teksty doktrynalne bezpośrednio dotyczące teologii duchowości, poznanie człowieka, zob. Ch.A. Bernard, Wprowadzenie..., s. 49-52.

71 Dokładniej: ,pojęcie duchowości chrześcijańskiej rozumiane jest zarówno jako praktyka życia duchowego, jak i usystematyzowana refleksja nad tymże życiem duchowym" (Leksykon duchowości katolickiej, red. M. Chmielewski, Lublin-Kraków 2002, s. 228).

72 J.B. Lotz, Wdrożenie w medytację nad Nowym Testamentem, tłum. J. Zychowicz, Kraków 1987, s. 9. 
wysiłek poszukiwania głębi relacji z Bogiem, a jednym z przejawów tego pragnienia jest zdolność do pochylania się nad słowem Bożym. Umiejętność ta ma dla współczesnego chrześcijanina zasadnicze znaczenie — od niej zależy kształt jego człowieczeństwa i chrześcijańskiego życia. Osoba świętej Urszuli Ledóchowskiej i teksty jej autorstwa mogą stanowić istotną pomoc w odczytywaniu słowa Bożego i wcielaniu go w życie.

$* * *$

Jeden $\mathrm{z}$ apoftegmatów opowiada, że pewnego dnia niektórzy bracia złożyli wizytę ojcu Antoniemu i poprosili go: „powiedz słowo: jak możemy być zbawieni?”. Starzec odpowiedział: „czy słuchaliście Pisma? Ono jest tym właściwym dla was”. Uczniowie odpowiedzieli: „,hcemy też usłyszeć coś od Ciebie, ojcze”73. Uczniowie przychodzą do ojca Antoniego, ponieważ chcą usłyszeć słowo od niego. Uważają go za człowieka Bożego, który wcielił w życie słowo, dlatego chcą czerpać z jego świętości i mądrości. Nie zwracają się do niego z powodu lekceważenia, niedoceniania czy niewystarczalności słowa Bożego; przeciwnie — szukają kogoś, kto pomoże im lepiej żyć słowem Bożym, kto nauczy ich duchowej walki. Dostrzegają, że warto nie tylko samemu modlić się i poznawać Pisma, lecz także korzystać z doświadczenia innych we wspólnocie Kościoła, którzy przeszli już pewien etap na drodze słuchania, rozważania i życia słowem Bożym $^{74}$.

Święta Urszula Ledóchowska jest osobą, od której można uczyć się, jak żyć słowem Bożym, jak je rozważać i wcielać w życie. Pismo Święte pełni bowiem zasadniczą rolę w myśli i życiu Założycielki Zgromadzenia Sióstr Urszulanek Serca Jezusa Konającego. Jej duchowość jest duchowością biblijną. Ponadto, Matka Ledóchowska swoim podejściem do Biblii wyprzedziła II Sobór Watykański. Sposób postrzegania i odczytywania Ewangelii, który reprezentowała, jest aktualny również i dziś.

Ze względu na ograniczoną objętość tego artykułu pokazałam wybrane aspekty duchowości biblijnej jedynie na podstawie Rozmyślań i Testamentu św. Urszuli Ledóchowskiej. Pisma te są zarazem najistotniejsze w celu poznania duchowości biblijnej Założycielki Zgromadzenia Sióstr Urszulanek Serca Jezusa Konającego. Należy zauważyć, że inne dzieła Matki Urszuli również zawierają liczne odniesienia biblijne, których przeanalizowanie mogłoby kiedyś dać pełniejszy obraz jej duchowości opartej na Piśmie Świętym.

${ }^{73}$ Zob. Powiedzenia Ojców pustyni, Serie alfabetica, Antoni 19, cyt. za: Nowe odczytanie codzienności. Teksty wschodnich i zachodnich Ojców Kościoła, thum. A. Koprowski, Warszawa 2017, s. 9.

${ }^{74}$ Zob. tamże. 


\section{Selected aspects of the biblical spirituality according to writings of Saint Ursula Ledóchowska}

\section{Summary}

The aim of this article is to present selected aspects of the biblical spirituality according to writings of Saint Ursula Ledóchowska. The Word of God has the central position in the spirituality of the Founder of the Congregation of the Ursuline Sisters of the Agonizing Heart of Jesus. Mother Ledóchowska is the author of Meditations, that contain considerations based on specific fragments of the Gospel, intended for each day of the year. Her Testament is also full of biblical references and permeated with the evangelical logic. According to Saint Ursula Ledóchowska the meditation of the Word of God in the spirit of faith enables us to learn more and get to know better the person of Jesus Christ and to deepen the relationship with Him. Mother Ledóchowska, by her attitude to the Holy Bible, was ahead of the Second Vatican Council's time. All her life was an active exegesis of the words of Christ.

\section{Keywords}

Christian spirituality, Ursula Ledóchowska, Bible, Gospel, meditation

\section{Słowa kluczowe}

duchowość chrześcijańska, Urszula Ledóchowska, Biblia, Ewangelia, rozmyślanie

\section{Bibliografia}

Benedykt XVI, Adhortacja ,Verbum Domini”, Watykan 2010.

Benedykt XVI, Rozważanie przed modlitwa Anioł Pański: Święci ukazuja prawdziwe oblicze Boga i człowieka, 9 VIII 2009, „L’Osservatore Romano” (wydanie polskie), 10 (2009), s. 41.

Bernard Ch.A., Wprowadzenie do teologii duchowości, tłum. J. Machniak, Kraków 1996. Gasperis F.R. de, Biblia - droga do Życia, tłum. A. Koprowski, Warszawa 2018.

Jan Paweł II, Adhortacja ,,Vita consecrata”, Watykan 1996.

Jan Paweł II, Przemówienie do zakonników w sanktuarium Serca Jezusowego w mieście Guatemala: Żywy depozyt charyzmatu założycieli [w:] tegoż, O życiu zakonnym. Przemówienia - Listy Apostolskie — Instrukcje, red. E. Weron, A. Jaroch, PoznańWarszawa 1984, s. 242-248.

Katechizm Kościoła katolickiego, Poznań 1994.

Ledóchowska U., Pisma zakonne, Pniewy 2000.

Ledóchowska U., Rozmyślania dla Sióstr Urszulanek Serca Jezusa Konającego, t. 1, Pniewy 2000.

Ledóchowska U., Rozmyślania dla Sióstr Urszulanek Serca Jezusa Konającego, t. 2, Pniewy 2000. 
Leksykon duchowości katolickiej, red. M. Chmielewski, Lublin-Kraków 2002.

Lotz J.B., Wdrożenie w medytację nad Nowym Testamentem, tłum. J. Zychowicz, Kraków 1987.

Misztal W., Ewangelia w duchowości św. Urszuli [w:] „, Otrzymała od Ducha Świętego wielki charyzmat”. Św. Urszula Ledóchowska i Urszulanki Serca Jezusa Konającego, red. M. Krupecka, W. Misztal, Kraków 2012, s. 119-143.

Papieska Komisja Biblijna, Interpretacja Pisma Świętego w Kościele, Watykan 1993.

Pismo Święte Starego i Nowego Testamentu. Biblia Tysiąclecia, Poznań 2002.

Rohr R., Rzeczy ukryte. Odkrywanie duchowości Pisma, tłum. M. Chojnacki, Kraków 2015.

Skrzypczak R., Wstęp [w:] J. Bątkiewicz-Brożek, Jezu, Ty się tym zajmij!, Kraków 2017, s. $11-24$.

Sobór Watykański II, Konstytucja dogmatyczna o Objawieniu Bożym „Dei Verbum”, Poznań 2002. 